\title{
Acute Kidney Injury: Treatment with Unani Medicine-Case Report
}

\author{
Muhammad Shakil Ahmad Siddiqui1, ${ }^{2}$, Khan Usmanghani2 \\ ${ }^{1}$ Rafah-e-Aam Dawakhana Ajmali (Clinics) and Rafah-e-Aam Herbal Laboratories, Karachi, Pakistan \\ ${ }^{2}$ Faculty of Eastern Medicine, Hamdard University, Karachi, Pakistan \\ Email: rafaheaam@gmail.com
}

Received 1 April 2014; revised 6 May 2014; accepted 2 June 2014

Copyright @ 2014 by authors and Scientific Research Publishing Inc.

This work is licensed under the Creative Commons Attribution International License (CC BY).

http://creativecommons.org/licenses/by/4.0/

(c) (i) Open Access

\begin{abstract}
A male named Anwer Jamal, age 45 years, married, visited Clinic Rafaheaam Dawakhana Ajmali on March 29, 2013, with history of glomerulonephritis, inherited renal diseases, hypertension and previously hooked on voltaren 50 (Diclofenic Sodium, $50 \mathrm{mg}$ ) and was not on dialysis. Different diagnostic parameters showed the patient was suffering from acute renal failure according to the RIFLE criteria. AKI is life threatening when kidneys suddenly is unable to filter waste products from blood. The patient was treated and managed with herbal medicines according to Unani system of medicine. Reversal of the parameter such as serum creatinine from $7.90 \mathrm{mg} / \mathrm{dl}$ (6.58 fold high) to $0.81 \mathrm{mg} / \mathrm{dl}$ within two weeks clearly shows the remarkable recovery in a short period of time. During this period the other related parameters e.g. blood urea nitrogen (BUN), serum albumin, albuminuria, blood pressure were also normalized whereas clinical sign and symptom exhibited improvement.
\end{abstract}

\section{Keywords}

Acute Kidney Injury, Diagnosis, Unani Treatment, Outcome

\section{Introduction}

Acute Kidney injury is characterized by the sudden impairment of function occurring over a period of hours and days. A diagnose of AKI is made on the basis of presence of elevated serum creatinine and/or blood urea nitrogen (BUN) levels and/or decreased urine out put, despite their well known limitation. Therefore, acute kidney injury is the abrupt loss of kidney function resulting in the retention of urea and other nitrogenous waste products and in the dysregulation of extra cellular volume and electrolytes. The acute kidney injury specifies the sudden reduction in kidney function and is associated with morbidity and mortality. The acute renal failure cases

\footnotetext{
${ }^{*}$ Corresponding author.
} 
are quite increasing in those patients with critical illnesses and drug adverse reactions. The causes are attributed sepsis [1], chronic dialysis [2], and varied critical condition. The procedures in clinical care adopted are ventilation, vasoactive intravenous medications, nutritional support, and dialysis. The aim of this article is to exhibit the implication and usefulness of Unani (herbal) medicine synergistic effects to obtain optimal patient outcomes in the following case study of kidney injury. Unani medicine is comprehensive system of medicine prevalent in south Asia including Pakistan. In this system the naturally occurring substances, mostly herbal medicine are used for the treatment of different types of diseases including kidney. Single medicine (Muffradat) is preferred over compound (Murrakabat) formulations for balancing the homeostasis of the body [3].

\section{Case Presentation}

A 45-year-old man was visited to the Clinic at Rafaheaam Dawakhana Ajmali, Karachi, on March, 31, 2013, with the complain of recurrent right flank pain, generalized swelling, bilateral pedal edema, anorexia, constipation, insomnia epigastric pain, fatigue, nausea, vomiting and mild fever without shivering, head ache and history of dark brown urine 2 days before, no mass or tenderness in the renal pelvis. The patient had a history of extensive use of NSAID e.g. volteran 50 for lumber pain. The patient had a history of hypertension for the last 8 years; renal stone cleared 9 years back and no history of diabetes, tuberculosis and ischemic heard disease. Whereas pain in the right lumber since last many years. The patient had complained of hematuria and renal stone in 1997.

The patient had been evaluated at Hospital Sind Institute of Urology and Transplantation (SIUT), Karachi, on March 29, 2013, where he was evaluated for ultrasound of KUB, CBC, blood urea, serum creatinine, serum electrolytes and urine D/R. ultrasound study shows; right kidney mild echogenic, mild fullness at proximal ureter; no stone seen. left kidney is echogenic. CBC; Hb $12.5 \mathrm{G} / \mathrm{dl}$, Htc $35.9 \%$, WBC $9.5 \times 10 \mathrm{E}^{9} / \mathrm{L}$, platelets $402 \times$ $10 \mathrm{E}^{9} / \mathrm{L}$, urea $139 \mathrm{mg} / \mathrm{dl}$, serum creatinine $7.90 \mathrm{mg} / \mathrm{dl}$, sodium $126 \mathrm{meq} / \mathrm{L}$, potassium $4.2 \mathrm{meq} / \mathrm{L}$, chloride 101 meq/L, bicarbonate $19 \mathrm{meq} / \mathrm{L}$, in urine albumin ${ }^{3+}$ present. The blood pressure was 180/100 $\mathrm{mm} \cdot \mathrm{Hg}$. No surgical history found. Patient has family history of kidney disease, hypertension, diabetes maternal and history of hypertension and cardiac disease in paternal. O/E_chest clear, cardiac $\mathrm{S}_{1} \mathrm{~S}_{2}$, audible, no murmur, bilateral pedal edema present, P/A abdomen soft, no mass or hardness found. On examination at March 30, 2013, generalized swelling present, abdomen was soft no tenderness found and blood pressure was 180/110.

On March 31, 2013, the temperature was $99.0^{\circ} \mathrm{F}$, the blood pressure $140 / 80 \mathrm{~mm} \cdot \mathrm{Hg}$, the pulse $68 \mathrm{bpm}$, the respiratory rate 14 breaths per minute. generalized and orbital edema moderate, skin dry, taste of mouth bitter, nausea mild, vomiting mild, no hiccup, right lumber pain moderate, urine output low, constipation moderate, abdomen was soft whereas rest of the examination was otherwise normal.

On 02 April, 2013, temperature was $99.0^{\circ} \mathrm{F}$, blood pressure $170 / 80 \mathrm{~mm} \cdot \mathrm{Hg}$, pulse $70 \mathrm{~b} / \mathrm{min}$., lumber pain moderate, nausea mild, and no vomiting and mild headache present. Biochemistry was: BUN $72 \mathrm{mg} / \mathrm{dl}$, Serum albumin $2.76 \mathrm{~g} / \mathrm{dl}$, serum calcium $7.97 \mathrm{mg} / \mathrm{dl}$, serum electrolyte levels was sodium $130 \mathrm{mEq} / \mathrm{l}$, potassium 4.4 $\mathrm{mEq} / \mathrm{l}$, chloride $96 \mathrm{mEq} / \mathrm{l}$, bicarbonate $26 \mathrm{mEq} / \mathrm{l}$. Urinalysis showed a $\mathrm{pH}$ of 6.0, specific gravity 1.015, protein $3.0 \mathrm{~g} / \mathrm{l}^{(+3)}$ Occult blood negative; there were 8 - 10 pus cells, red cells nil, no cast and moderate bacteria.

On 03 April, 2013, ultrasound report was both kidneys appear slightly echogenic. No lesion was seen in liver, gall bladder, common bile duct, pancreas, spleen and retroperitoneum. On 04 April, 2013, Serum creatinine level was $5.10 \mathrm{mg} / \mathrm{dl}$.

On 5 April, 2013, temperature was $99.0^{\circ} \mathrm{F}$, BP. 160/90 mm.Hg., generalized and orbital edema moderate, lumber pain moderate, nausea mild, pulse $70 \mathrm{~b} / \mathrm{min}$., epigastric burning moderate, skin normal, nausea mild, no vomiting, urine output low, constipation mild.

On 08 April, 2013, temperature was 98.6, B.P. 140/80 mm·Hg., Pulse $70 \mathrm{~b} / \mathrm{min}$. generalized edema moderate, orbital edema moderate, sleep was normal, pedal edema mild, no nausea, no vomiting, right lumber pain mild and urine output increased.

On 12 April, 2013, temperature was $98.6^{\circ}$ F, B.P. 125/80 mm·Hg., pulse 72b/min., no generalized, orbital, pedal edema, right lumber pain mild, mild epigastric burning, no nausea, no vomiting, Mouth taste was normal, sleep normal.

On 15 April, 2013, laboratory reports was; BUN $5.6 \mathrm{mg} / \mathrm{dl}$., S. creatinine $0.81 \mathrm{mg} / \mathrm{dl} .$, S. albumin $2.86 \mathrm{~g} / \mathrm{dl}$., HbA1c 5.4\%; urine detail report was specific gravity 1020, $\mathrm{pH} 6.0$, protein ${ }^{+3}$, pus cells $8-10$, RBC nil, cast granular 4 - 5/LPF, bacteria few.

20 April, 2013 temperature was $99.0^{\circ}$ F, B.P. $120 / 80 \mathrm{~mm} \cdot \mathrm{Hg}$, no edema, lumber pain mild, no nausea, no vo- 
miting, no epigastric burning, bowl movement normal, urine output normal but the medicine used continue for more days.

According to RIFLE criteria (Table 1) of kidney damages classification; the patient is frame on the elevation of serum creatinine basis. The patient's serum creatinine level was $7.90 \mathrm{mg} / \mathrm{dl}$. This increase in the level of serum creatinine is 6.58 folds from the baseline $1.2 \mathrm{mg} / \mathrm{dl}$. It is renal failure Stage 3 .

The patient kidney functions and other tests are given in Table 2.

\section{Unani (Herbal) Medicine [4]}

Unani Prescription 1. Majun Mussafi Khas: Chob Chini (Smilax chinensi Linn) 300 mg, Sana Makki (Cassia senna Linn) 200 mg, Turbud (Ipomea turpenthum R.Br.) 50 mg Nigand Babri (Vitex negundo Linn) $200 \mathrm{mg}$, and Qurs Rasoot: Rasoot (Berberis aristata D.C.) $160 \mathrm{mg}$, Haleela Zard (Terminalia chebula Retz half ripe fruit) 160 mg. at morning; Qurs Podina: Zinjabeel (Zingiber officinale Rosc) 100 mg, Kala Zeera (Carum carvi Linn) 100 mg, Podina (Mentha piperita Linn) 150 mg, Ajwain (Trachyspermum ammi (L.) Sprague) 150 mg, Filfil Daraz (Piper longum Linn) $0.2 \mathrm{mg}$. at noon after lunch; Habb e Sibr (Aloe vera L. Burm f.) 100mg for constipation, Itrifal Kishnizi: Haleela Zard (Terminalia chebula Retz) $0.43 \mathrm{mg}$, and Haleela Siyah (Terminelia chebula Retz. uripe fruit) $0.21 \mathrm{mg}$ and Kashneez (Coriandrum sativum Linn) $0.21 \mathrm{mg}$, Hab-e-Fishar (Rauwolfia serpentina (L.) Benth ex Kurz) $1.20 \mathrm{mg}$ (for blood pressure) at night after meal. This prescription was used for 4 days.

Unani Prescription 2. Majun Mussafi Khas: Chob Chini (Smilax chinensi Linn ) 300 mg, Sana Makki (Cassia senna Linn) 150 mg, Turbud (Ipomea turpenthum R.Br.) 50 mg Nigand Babri (Vitex negundo Linn) 150 mg, Sherbet Bazoori: Each dose $25 \mathrm{ml}$ contains aqueous extract Kasni (Cichorium intybus Linn) $2.0 \mathrm{mg}$, Kharpazza (Cucumis melo Linn $2.0 \mathrm{mg}$ ), Badyan (Foeniculum vulgare Mill) $2.0 \mathrm{mg}$ and Sodium bicarbonate Tablet after meal; Itrifal Kishnizi: Haleela Zard (Terminalia chebula Retz) $0.43 \mathrm{mg}$, and Haleela Siyah (Terminelia chebula Retz. uripe fruit) $0.21 \mathrm{mg}$ and Kashneez (Coriandrum sativum Linn) $0.21 \mathrm{mg}$. at night administered for 16 days.

Unani Prescription 3. Jawarish Zarooni Saida: Badiyan (Foeniculum vulgare Mill) $1.50 \mathrm{mg}$, Filfil Siyah (Piper nigrum Linn.) 1.50 mg, Ajwain (Trachyspermum ammi (L.) Sprague) 1.50 mg, Post Beikh Karafs (Apium graveolence Linn.) $1.50 \mathrm{mg}$, Qaranfal (Caryophyllus aromatica Linn.) $1.50 \mathrm{mg}$, Tukhme Gazer (Daucus carota Linn.) $1.50 \mathrm{mg}$, Tukhme Karafs (Apium graveolence Linn.) $1.50 \mathrm{mg}$, Tukhme Kharpaza Cucumis melo Linn.) $1.50 \mathrm{mg}$, Aqirqarha (Anacylus pyrethrum DC.) $0.6 \mathrm{mg}$, Bisbasa (Myristica fragrans Houtt) $0.6 \mathrm{mg}$, Dar Chini-

Table 1. Risk of renal failure, injury to kidney, failure of kidney function, loss of kidney function, and end-stage renal failure (RIFLE) and Acute Kidney Injury Network (AKIN) classification schemes for Acute Kidney Injury (AKI).

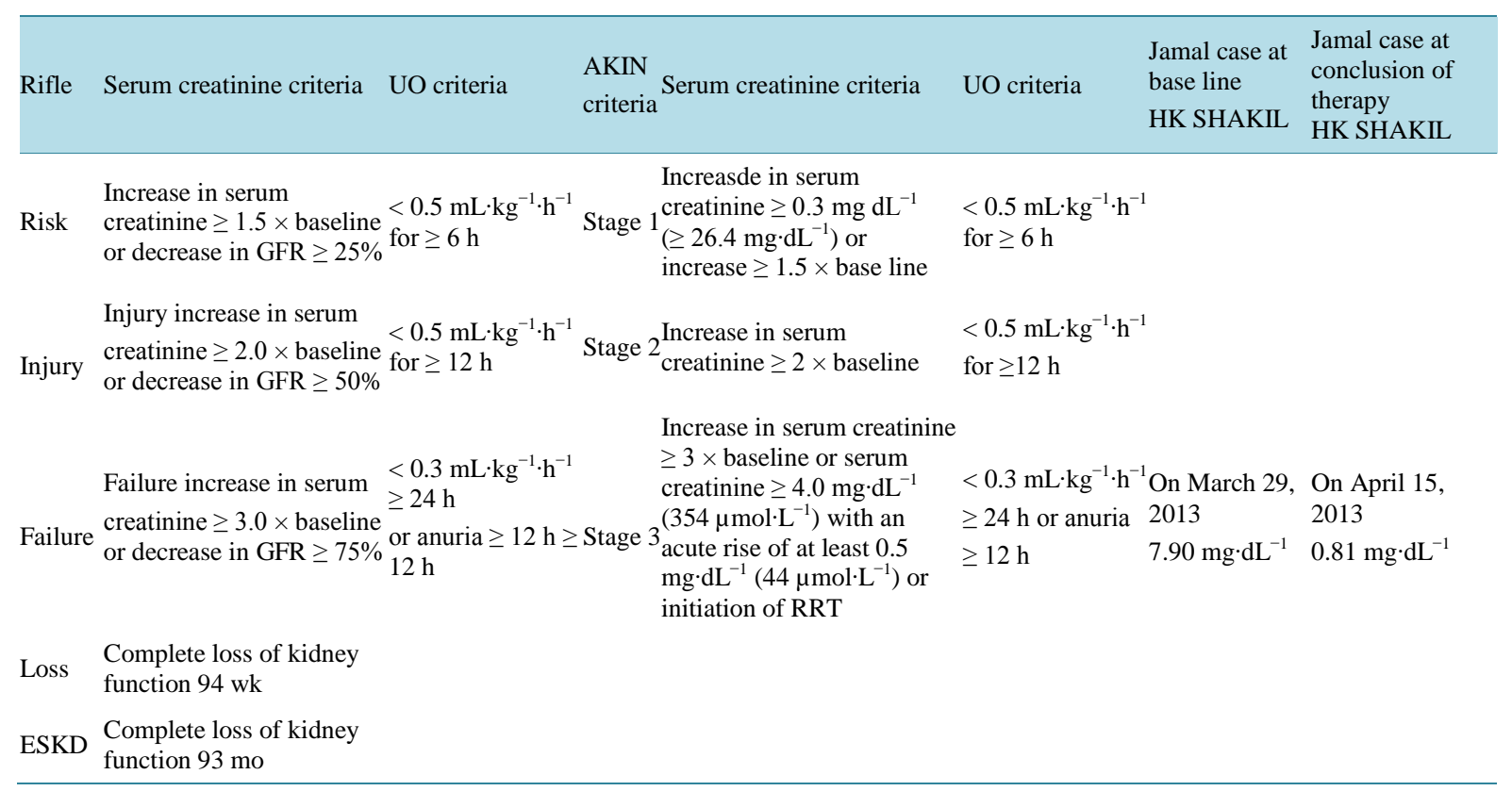

ESKD indicates end-stage kidney disease; GFR, glomerular filtration rate; RRT, renal replacement therapy. 
Table 2. Pateint kidney function tests.

\begin{tabular}{|c|c|c|c|c|c|c|c|c|}
\hline TEST & $\begin{array}{c}\text { 29-03-2013 } \\
\text { Before } \\
\text { treatment }\end{array}$ & 02-04-2013 & 04-04-2013 & $\begin{array}{c}\text { 15-04-2013 } \\
\text { After } \\
\text { treatment }\end{array}$ & $\begin{array}{l}\text { 06-04-2013 } \\
\text { Follow up }\end{array}$ & $\begin{array}{l}\text { 08-05-2013 } \\
\text { Follow up }\end{array}$ & $\begin{array}{l}\text { 12-05-2013 } \\
\text { Follow up }\end{array}$ & Normal range \\
\hline Hemoglobin & 12.50 & & & & & & & 0.85 - $1.35 \mathrm{mg} \mathrm{dL}$ \\
\hline Creatinine & 7.90 & & 5.10 & 0.81 & & 0.87 & 0.76 & 0.85 - $1.35 \mathrm{mg} \mathrm{dL}$ \\
\hline BUN & 64.9 & 72.0 & & 5.6 & & & & $5.20 \mathrm{mg} \mathrm{dL}$ \\
\hline Albumin, Serum & & 2.76 & & 2.86 & & & & 3.5 - 5.2 mg dL \\
\hline Urine albumin & +3 & +3 & & +3 & & 0 & 0 & NIL \\
\hline Pus cells & & 10 & 10 & & & 2 & 6 & $1-2$ \\
\hline $\mathrm{RBC}$ & & 0 & & & & & & NIL \\
\hline Cast & & & & $5 G$ & & & & NIL \\
\hline Bacteria & & MOD & & Few & & & Few & NIL \\
\hline Calcium & & 7.79 & & & & & & $8.6-10.2$ \\
\hline Chloride & & 96 & & & & & & $104-114$ mEq/1 \\
\hline Sodium & & 130 & & & & & & 136 - $146 \mathrm{mEq} / 1$ \\
\hline Potassium & & 4.4 & & & & & & 3.6 - $5.1 \mathrm{mEq} / 1$ \\
\hline Bicarbonate & & 26 & & & & & & $23-29 \mathrm{mEq} / 1$ \\
\hline Blood Pressure & $180 / 100$ & $170 / 95$ & $160 / 90$ & $142 / 85$ & $120 / 80$ & & & \\
\hline
\end{tabular}

(Cinnamomum zeylanicum Linn) $0.6 \mathrm{mg}$, bid for 15 days.

The patient was treated at Rafah-e-Aam Dawakhana Ajmali (Clinics), Karachi and was prescribed and administred the Unani (herbal) compound and simple medicine as mentioned earlier. The treatment was started on March 29, 2013, at first Unani preparation I for four days, thereafter, Unani preparation 2 was given for 16 days, and the patient recovered from creatinine and other biochemical and physiological parameters. In order to stabilize patient general health paradigm Unani preparation 3 was then continued for 15 days. During the treatment the following clinical and pathological features were observed.

\section{Follow-Up}

The follow up monitoring of the patient was carried out. On 08 May, 2013, test repeated report was serum creatinine $0.87 \mathrm{mg} / \mathrm{dl}$. urine specific gravity 1020, $\mathrm{pH}$ 6.0, protein nil, blood nil, us cells nil, cast nil, crystals nil, bacteria nil. patient was evaluated clinically and blood pressure was 120/80 mm·Hg, no lumber pain, no edema, urine output was normal all other complains were also normal.

Whereas on June 12, 2013, the serum creatinine $0.76 \mathrm{mg} / \mathrm{dl}$, and urinary creatinine $100.8 \mathrm{mg} / \mathrm{dl}$. were reported, urine D/R specific gravity 1.030, pH 6.0, albumin negative, blood nil pus cell 4 - 6/HPF, RBC, casts, crystals were nil, bacteria reported few and $24 \mathrm{hrs}$. The creatinine clearance reported at $64.4 \mathrm{ml} / \mathrm{min}$. (60 - $170 \mathrm{mg} \mathrm{dL}$ ).

\section{Discussion}

Approximately (1\% to 2\%) free creatine in muscles irreversibly converts to creatinine which in turn released into blood and ultimately excreted by the kidney [5]. It has been cited in the literature that herbal treatment was initiated treatment by utilizing over the counter herbal dosage form design that resulted in the improvement of laboratory parameter for cases of chronic renal failure. Herbal Chinese Formula: Rehmaniae Rx, Dioscoreae Rz, Corni Fr, Poria cocos Rx, Alismatis Rz, Cinnamomi Cx, Aconiti Rx. Ayurvedic Herbal Formula: Didymocarpus pedicellata, Saxifraga ligulata, Rubia cardifolia, Ocimum basilicum, Achyranthes aspera, Cyperus rotundus, Crataeva religiosa, and Uva ursi. Nagasaka and associates [6] have reported four cases of chronic renal failure 
effectively treated with Astragalis radix. Where in it reduces serum creatinine level, but it did not improve BUN, proteinuria and anemia [7]. Zhong et all in a review article have cited that Traditional Chinese herbal medications are utilized for treatment of chronic kidney diseases in China and many other Asian countries. These are decoction of Astragalus with Angelica sinensis, Rheum palmatum L and its components: emodin and rhein, decoctions of Radix bupleuri and components of R. bupleuri (saikosaponin a and d), Cordyceps sinensis and its component H1-A, Extracts of Tripterygium wilfordii Hook and component Triptolide (PG490), have been used to treat glomerulonephritis, calcium influx inhibition, vasodilatation, antithrombosis, antioxidation, anti-inflammation, and immune regulation, decreases proteinuria and improves the plasma levels of total cholesterol and albumin in patients with nephrotic syndrome, treatment decreased proteinuria and glomerulosclerosis, decreased urinary protein excretion in a rat model of subtotal nephrectom [8].

Acute kidney injury has become increasingly prevalent in Pakistan and uncertainty about the incidence of acute kidney injury limits awareness of the problem and its treatment modes. The reason could be gastroenteritis, or infections, diarrhea, poisoning, malaria, or septic abortion. The treatment is costly in developing regions, so the herbal medicine therapy could be an alternate to eradicate causes of acute kidney injury, and here we report evidence-based management.

\section{Conclusion}

Unani herbal preparations have resolved acute kidney injury within 20 days, as analyzed by the BUN, serum creatinine and 24 hour serum creatinine clearance levels. Further follow up for another 15 days showed sustained improvement. Monitoring for another 15 days showed sustained improvement. Serum creatinine does not rise to abnormal levels until a large proportion of the renal mass is damaged, because the relationship between the glomerular filtration rate (GFR) and the serum creatinine level is not linear, especially early in disease. The data presented clearly represent where in creatinine level on March 29, 2013 at $7.90 \mathrm{mg} \mathrm{dL}$ and on April 15, 2013 it decrease to $0.81 \mathrm{mg}$ dL. Similarly the urine output gave better results and also the patient kidney function tests consisting of such as hemoglobin, BUN, albumin serum, urine albumin, pus cells, RBC, Cast, bacteria, calcium chloride, potassium, sodium, bicarbonate, blood pressure, $\mathrm{Hb}_{\mathrm{I}} \mathrm{C}$ after herbal treatment came within the normal range and matched with controls. The early treatment can help to optimize management and avoid the preventable complications of acute kidney injury.

\section{References}

[1] Kosinski, M. (2009) What's Old Is New again: AKI and ARF. 2009 NTI and Critical Care Exposition. AACN. www.aacn.org http://www.aacn.org/wd/nti/nti2009/docs/nti program schedule booklet.pdf

[2] Uchino, J., Kellum, A., Bellomo, R., Gordon, S., Doig, Y., Morimatsu, H., Morgera, S., Schetz, M., Tan, I., Bouman, C., Macedo, E., Gibney, N., Tolwani, A. and Ronco, C. (2005) Acute Renal Failure in Critically Ill Patients A Multinational, Multicenter Study. JAMA, 294, 813-818. http://dx.doi.org/10.1001/jama.294.7.813

[3] http://apps.who.int/medicinedocs/documents/s17558en/s17558en.pdf

[4] Kabir, H. (2003) Murakkabat (Unani Formulation). Shamsher Publication \& Distributor, Aligarh, 63, 80.

[5] Newman and Price, F.C. (2001) Non Protein Nitrogen Metabolites. In: Burtis, C.A. and Ashwood, A.R., Eds., Tietz Fundamental of Clinical Chemistry, W.B. Saunders Company, Philadelphia, 414-422.

[6] Nagasaka, K., Fukuda, H., Watanabe, T. and Ngata, Y. (2012) Report on Four Cases of Chronic Renal Failure Effectively Treated with Astragali Radix. Kampo Medicine, 63, 98-102. http://dx.doi.org/10.3937/kampomed.63.98

[7] Chang, C.H., Lin, C.Y., Tian, Y.C., Jenq, C.C., Chang, M.Y., Chen, Y.C., Fang, J.T. and Yang, C.W. (2010) Acute Kidney Injury Classification: Comparison of AKIN and RIFLE Criteria. SHOCK, 33, 247-252. http://dx.doi.org/10.1097/SHK.0b013e3181b2fe0c

[8] Zhong, Y., Deng, Y., Chen, Y., Chuang, P.Y. and He, J.C. (2013) Therapeutic Use of Traditional Chinese Herbal Medications for Chronic Kidney Diseases. Kidney International, 84, 1108-1118. 
Scientific Research Publishing (SCIRP) is one of the largest Open Access journal publishers. It is currently publishing more than 200 open access, online, peer-reviewed journals covering a wide range of academic disciplines. SCIRP serves the worldwide academic communities and contributes to the progress and application of science with its publication.

Other selected journals from SCIRP are listed as below. Submit your manuscript to us via either submit@scirp.org or Online Submission Portal.
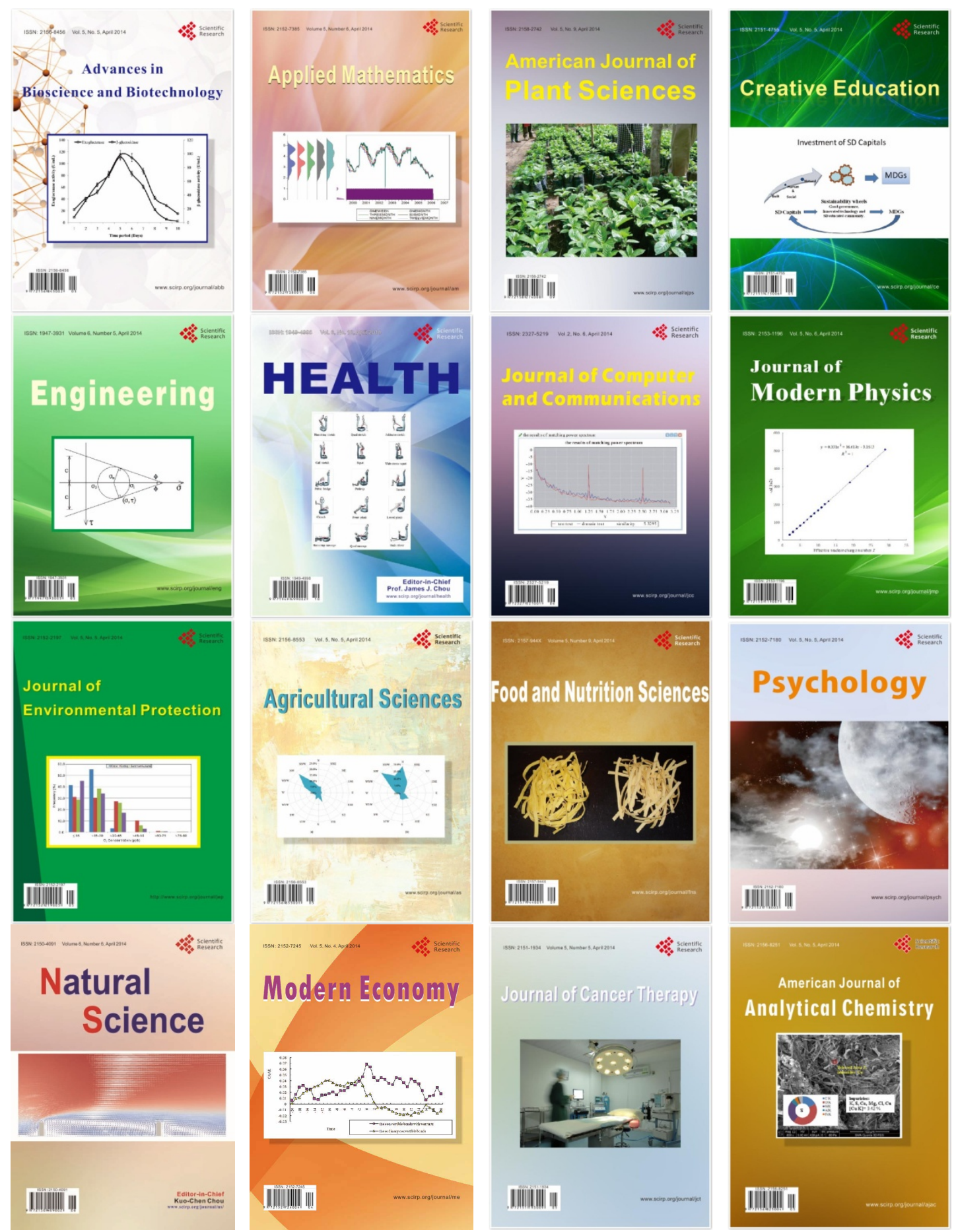